\title{
„Trzeba wierzyć, że życie coś znaczy”. Z Michałem Szczepańskim rozmawiają Anna Mateja i Anna Spiechowicz
}

\author{
"You Must Believe Life Means Something." Anna Mateja and Anna Spiechowicz in \\ Conversation with Michał Szczepański
}

Anna Mateja: Milion sto tysięcy znaków. Tyle liczył VI tom Dziennika Jana Józefa Szczepańskiego, który odczytał Pan z rękopisu, podobnie jak pięć wcześniejszych tomów, równie obszernych. Jak przepisuje się takiego kolosa?

Michał Szczepański: Wielkość była jedyną trudnością techniczną - 30 tys. stron zapisanych równym i wyraźnym pismem ojca w latach 1945-2002. Dopiero w ostatnich latach jego życia choroba Parkinsona czytelność zapisków pogorszyła na tyle, że w nielicznych miejscach nie było możliwe odtworzenie myśli autora. $Z$ tego powodu zdecydowałem się zakończyć edycję Dziennika na grudniu 2001 roku, mimo że ojciec prowadził go jeszcze przez kilka następnych tygodni. Nie sposób jednak odczytać treści notatek - przypominają pofałdowaną linię, a nie zapis.

Przez całe życie ojciec pisał jednak czytelnie, właściwie nie robiąc poprawek. Nie tylko w zapiskach osobistych, rozpoczętych 25 czerwca 1945 roku i nazwanych pamiętnikiem, który miał go „wyleczyć i wychować”. Podobnie było z tekstami literackimi. Rękopisy pokazują, że gdy zaczynał pisać, miał już niemal wszystko przemyślane. Problemy z odczytaniem pojawiały się jedynie wówczas, kiedy ojciec - ze względów oszczędnościowych, bo w Polsce Ludowej brakowało papieru - pisał na przykład na przebitce z maszyny do pisania. Dwustronnie i wiecznym piórem, przez co zdania przebijały na drugą stronę, stając się trudnym do rozszyfrowania hieroglifem.

A.M.: Dopadło Pana wrażenie przeżywania życia ponownie za sprawą notatek ojca?

${ }^{1}$ J.J. Szczepański, Dziennik, t. 1: 1945-1956, Kraków 2009, s. 6. 
M.S.: Jak najbardziej - przytrafiła mi się podróż w czasie. I jeśli spisywanie Dziennika bywało dla mnie niełatwe, to właśnie w takich momentach: $\mathrm{z}$ powodu emocji wywołanych dawnymi przeżyciami oraz związanym z nimi wejściem w życie wewnętrzne bliskiej mi osoby.

Byłem przekonany, że dobrze ojca znałem. I ja, i moje siostry, nie mówiąc o mamie, mieliśmy z nim bliskie relacje, czemu sprzyjała niemal stała jego obecność, bo pracował w domu. Poza tym ojciec pozwalał sobie przeszkadzać - zawsze można było wejść do jego pokoju ze swoją sprawą. Postrzegałem więc ojca jako człowieka równego uczuciowo. Raczej pogodnego, nigdy nie było widać po nim nawet przygnębienia. Tymczasem z Dziennika dowiedziałem się, jak często miewał nastroje, których nie wahałbym się nazwać depresyjnymi. Zaskoczeniem były też wyznania ojca, jak jest z siebie niezadowolony. Wątpił w wartość tego, co napisał.

A.M.: „Czytam Rok myśliwego Miłosza” - pisze Pana ojciec 6 października 1990 roku. „Porusza tam znów sprawę Sylwestra w Goszycach. Ze zdumieniem widzę, jak moja osoba plącze się w historii współczesnej polskiej literatury. U Michnika, u Trznadla, u Miłosza. Mam coraz wyraźniejszą świadomość intruza. Żaby, podstawiającej nogę do kucia. W sposób niezamierzony. Bo nie łudzę się już, bym należał do pierwszej ekipy"2. Pamięta Pan sytuacje, kiedy ojciec rozmawiał z Panem o swojej twórczości?

M.S.: Gdy byłem starszy, prosił mnie o opinię na temat niektórych, dopiero co napisanych przez siebie opowiadań. Mamę, która przepisywała rękopisy na maszynie, prosił o to za każdym razem. Zgłoszone poprawki wprowadzał, ale z reguły dotyczyły one drobnych spraw. Ze mną konsultował, na przykład język młodzieżowy albo slang filmowy przy okazji powstawania scenariuszy.

O pisaniu Dziennika ojciec nie mówił jednak nigdy, choć widzieliśmy na biurku skórzaną teczkę, w której znajdowały się kartki z notatkami. Wiedzieliśmy też, że kiedy uzbierała się ich pokaźna ilość, wywoził je do domu na Kopieńcu w Kasince Małej, który uważał za bezpieczne miejsce, i dołączał do stosu kartek znajdujących się w skrytce pod dachem. Nie znaliśmy ich treści, bo, naturalnie, nikt z nas nigdy do tego nie zaglądał. Przypuszczaliśmy, że są to notatki robocze. I takimi też zresztą były, gdyż ojciec wiele razy korzystał z nich podczas pisania, odświeżając informacje z podróży, spotkań, ale też własnych myśli. Traktował te notatki niczym „rozbiegówkę” przed właściwym pisaniem - sposób na podtrzymanie gotowości pisarskiej, jeśli akurat nie miał na biurku żadnej większej roboty literackiej. Coś jak Dziennik Samuela Pepysa, prowadzony w latach 1660-1669, w którym ten angielski kupiec opisuje drobiazgowo swoją codzienność, nie wyłączając tego, co się dzieje wokół. Pomysł publikacji notatek ojca pojawił się późno.

\footnotetext{
2 Tenże, Dziennik, t. 6: 1990-2001, Kraków 2019, s. 76.
} 
Anna Spiechowicz: Po raz pierwszy chyba 30 lat po rozpoczęciu ich prowadzenia. „Zaczynam liczyć się z tym, że ten pamiętnik będzie kiedyś publikowany" - notuje Jan Józef 25 lipca 1975 roku, uzupełniając notatki o pominięte kiedyś wydarzenia. „Po mojej śmierci. Może uda mi się zachować mimo to jego szczerość. Jeśli nie czuję teraz skrupułów, to dlatego, że widzę, iż ma on szansę być dokumentem naszych czasów - w większym pewnie stopniu niż moje książki”3.

M.S.: Dwadzieścia lat później, kiedy ojciec spaginował wszystkie zapiski, wspomina o tym ponownie, nieco melancholijnie: „Mam dziwne wrażenie, że zawarta w nich rzeczywistość jest jak gdyby niedojrzała. Że dojrzeje dopiero, gdy mnie już w niej nie będzie. Czyli że cały ten plankton codzienności, którego nie potrafiłem ująć, stanie się już definitywnie nieważny. Nie do odtworzenia. Jest w tym jakby cicha zgoda na oddanie tego pamiętnika (którego nikomu nie pokazuję) obcym, bezstronnym oczom”".

A.M.: Inaczej niż w przypadku zapisków Pepysa, których wybór ukazał się dopiero w 1825 roku, a całość siedem dekad później, edycja Dzienników Pana ojca rozpoczęła się zaledwie sześć lat po jego śmierci. Czytelnicy chwalą sobie, że nie musieli czekać na komentarz do współczesności, na przykład pół wieku. A rodzina?

M.S.: Mama, która zmarła w 2006 roku, nie miała nic przeciwko temu, zwłaszcza że ojciec wyznał jej około 2001 roku, czyli dwa lata przed śmiercią, że publikacja jego zapisków dziennikowych miałaby sens. Wykonanie tego zadania powierzono mnie. W obawie, że nikt z młodszego pokolenia nie szarpnie się na taką robotę, uznałem, że nie ma na co czekać. Bałem się też, że myszy, które były zagrożeniem jeszcze w Kasince, zniszczą pracę ojca. Nie bez znaczenia była jakość papieru, kruszącego się z powodu zakwaszenia, więc czym prędzej należało oddać rękopisy w ręce fachowców. I tak się stało - znalazły się w Bibliotece Narodowej.

A.M.: Kiedy pojawiały się wątpliwości, czy jakiś fakt lub opinię należy „oddać obcym oczom"?

M.S.: Zapiski ojca wydano bez znaczących skrótów. Wypadły pojedyncze zdania, opisujące osobiste sprawy innych ludzi, wciąż żyjących, którzy mieliby prawo odebrać ich upublicznienie jako naruszenie dóbr osobistych. Przerwy zaznaczono - zwyczajowo - trzema kropkami w nawiasach. Zdarzają się też,

3 Tenże, Dziennik, t. 4: 1973-1980, Kraków 2015, s. 211.
${ }^{4}$ Tenże, Dziennik, t. 6, dz. cyt., s. 401-402. 
zwłaszcza w tomie szóstym, miejsca (z reguły są to pojedyncze słowa), których nie udało się odczytać.

Miałem wątpliwości, spisując pierwszy tom Dziennika, czy warto przedrukowywać część mikropowieści, której fragmenty ojciec zaczął wplatać w zapiski dziennikowe w kwietniu 1955 roku. Zwłaszcza że książka ukazała się później w Wydawnictwie Literackim5. Ale redaktor Małgorzata Nyczowa, wydawca, była pewna, że jak najbardziej należy to zachować. I chyba dobrze, bo w ten sposób powstało intrygujące zestawienie: losy bohaterów literackich hiszpańskojęzycznego państwa faszystowskiego przeplatają się z perypetiami osób żyjących w realiach polskiego stalinizmu.

A.S.: Zgodnie z zasadami krytyki genetycznej dziennik to nie tylko obraz bieżącej rzeczywistości, ale także prywatne archiwum jego autora, więc należy go analizować w całości. Co zachowywał Jan Józef między kartami Dziennika? Wycinki prasowe? Zasuszone kwiaty? Listy od wielbicieli?

M.S.: Listy tak, ale na zasadzie przypadku, nie metody. Tylko część z nich miała związek z notatkami. Większość znalazła się w skórzanej teczce chyba tylko dlatego, że listy plątały mu się po biurku. Wśród tych przypadkowych szpargałów zachował się na przykład wojenny meldunek (napisany na maszynie), przekazany przez ojca lokalnemu dowództwu Armii Krajowej, na temat stanu niemieckich sił wojskowych i policyjnych stacjonujących w okolicach Kasinki Małej: liczba żandarmów, położenie posterunku czy miejsca parkowania samochodu.

Z czasów wojny niewiele zapisków było dane ojcu zachować. Jego ówczesne życie można zrekonstruować na podstawie opowiadań, na przykład z tomów Dzień bohatera ${ }^{6}$ i Motyl $l^{7}$ albo noweli Euna za lasem ${ }^{8}$. I, oczywiście, wspomnień, do których ojciec wraca w Dzienniku na różnych etapach życia. W kasińskim domu ocalały natomiast zeszyty z jego przedwojennymi opowiadaniami, które publikował w gazetce z Włodzimierza Wołyńskiego podczas odbywanej tam służby wojskowej. Na Kopieńcu moja młodsza siostra Katarzyna odnalazła również zapiski naszej babci, Marii ze Znatowiczów Szczepańskiej, z czasów wojny oraz listy ojca pisane do niej w trakcie nauki w podchorążówce.

A.S.: Profesor Marta Wyka nazwała sześć tomów Jana Józefa „dziennikiem pisanym za dnia”, nawiązując do Dziennika pisanego nocą Gustawa Herlinga-Grudzińskiego. U Szczepańskiego historyczne wydarzenia sąsiadują bowiem z wyliczaniem gospodarskich zajęć: koszeniem trawy w ogrodzie, podbieraniem

\footnotetext{
5 Tenże, Pojedynek, wyd. 1, Kraków 1957 (powieść).

6 Tenże, Knajpka przy torach i Gdzie nów zachodzi, wyd. 1, Warszawa 1959 (opowiadania).

7 Tenże, Przeprowadzka i Stajnia na Celnej, wyd. 1, Warszawa 1962 (opowiadania).

${ }^{8}$ Pierwodruk: „Krytyka” 1987, nr 23-24; przedruk: Roztogi, Kraków 2001.
} 
miodu pszczołom, sadzeniem kolejnych drzewek owocowych zjadanych przez zające. Wiemy nawet, jak obrodziły trześnie, ałycze czy orzechy w kolejnych sezonach kasińskiego gospodarstwa.

M.S.: Ta proza życia była naszą - czyli rodziców oraz moich sióstr, Anuli i Kasi - normalnością. Jej integralną część stanowił bezpośredni kontakt z przyrodą. W ogóle rodzice zwracali nam uwagę na fizyczną stronę świata: zarówno na jego piękno, jak i na obowiązek pracy, nie tylko umysłowej. W drewnianym domu w Kasince nie było przecież bieżącej wody - tę nosiło się w wiadrach i baniakach kawał drogi, bo z wybudowanego przed wojną ośrodka Young Men's Christian Association (w naszych czasach zarządzało nim Ministerstwo Edukacji Narodowej i urządzało tam obozy dla młodzieży). Tam był kran z wodą doprowadzoną ze strumienia, do którego przychodziliśmy nawet kilka razy dziennie. Z kanalizacji mieliśmy sławojkę, obrośniętą krzakami jaśminu. Zakupy trzeba było wnosić na Kopieniec, idąc dobre 40 minut od szosy pod górę.

Dom w Kasince był enklawą na złe czasy, nie tylko dla nas, więc w lecie kasiński dom był pełny po dach. Przyjeżdżali bliżsi i dalsi krewni z dziećmi, przyjaciele, przygodnie poznani znajomi. Każdy miał obowiązki. Do dzisiaj jednak wiele z ówczesnych dzieci pamięta wakacje w Kasince jako najlepsze w życiu. Moje siostry i ja uważamy z kolei czas spędzony na Kopieńcu za lepszą połowę życia. Tam była absolutna wolność, było pięknie, zawsze trwało lato... I to było świetne.

A.M.: W mieszkaniu przy ulicy Helclów działo się podobnie. Pana ojciec notuje skrupulatnie, kto przyjechał, kto się rozpakowuje, jakich kolegów przyprowadziły kolejne dzieci.

M.S.: Było jeszcze coś - prowadziłem jako młody człowiek bogate życie towarzyskie. Pewnego dnia Wawrzek, mój przyjaciel, a syn Tadeusza Brzozowskiego, malarza, przyprowadził młodych ludzi, którzy przyjechali do Polski z Kanady czy Australii: piękna dziewczyna i chłopak. Zaprosiliśmy, także moja siostra Kasia, kolejnych znajomych i przyjaciół (mama była w Kasince). I kiedy impreza trwała już od kilku dobrych dni - wrócił ojciec z podróży. Wszedł do mieszkania pełnego ludzi, z których większości nie znał. Przy łazience jakaś nieznana panienka zagadnęła go: „pan też jest znajomym Wawrzyńca?”...

Ojca takie sytuacje w żaden sposób nie deprymowały. Wręcz przeciwnie był ciekaw nieznanych ludzi, którzy przewijali się przez nasz dom. Zagraniczni goście przekazywali więc sobie krakowski adres moich rodziców niczym gościnną „,metę”, gdzie na pewno zostanie się przyjętym. A przecież bywały i takie sytuacje, kiedy ktoś zamieszkiwał u nas na dłużej, na przykład mój kolega germanista poznany podczas robotniczych praktyk studenckich, który nie dostał akademika i zatrzymał się przy Helclów na bodaj trzy miesiące. A jeszcze byli 
Diana Dyjak Montes de Oca, Patricia Grimsted, Leonor Salazar, Boguś Kostia, Kuba Radomski...

A.M.: Oddajmy głos Pana ojcu: „Wspaniały, męczący, wzruszający, nieznośny młyn przyjaźni i zaufania” - pisze 3 grudnia 1977 roku. „Michnik z Kłoczowskim rano i od razu zbiegowisko. Jak na lep Staszek [Krasnowolski - A.M.], Wawrzek [Brzozowski - A.M.], Miłek [Kuniński - A.M.]. Równocześnie Michał ze swoją ekipą Jugosłowian (przyjechali kręcić film o Lemie) - wchodzą i wychodzą. Diana przeprowadza się przy pomocy znajomego z samochodem, Malcolm, przyjaciele Malcolma. Trudno nadążyć z otwieraniem drzwi i odbieraniem telefonu"'. Jak to znosiła Pana mama - Danuta z Wolskich Szczepańska?

M.S.: Była mechanizmem napędzającym i porządkującym nasze życie. Za jej sprawą jakoś tak się działo, że kiedy na przykład zjawiało się przy stole pięć niespodziewanych osób, obiadu starczało dla wszystkich. Jeszcze większym wyzwaniem było prowadzenie domu podczas wielomiesięcznych podróży ojca. I umiała dzielnie temu sprostać, mimo że nasza trójka, choć angażowała się w domowe prace, sprawiała też kłopoty. Wsparciem było duże grono uczynnych ciotek i przyjaciele, którzy wpadali o każdej porze, bo to były jeszcze czasy bez konieczności telefonicznego umawiania się.

Przypuszczam, że mama nie przepadała za tymi rozłąkami, ale nigdy przeciwko nim nie protestowała, nawet przed wielomiesięczną wyprawą ojca na Spitsbergen w 1959 roku czy stypendium w Iowa City na przełomie lat 1968/1969. Jeżeli jakieś rozmowy na ten temat się odbywały, nie mogłem być ich świadkiem, bo rodzice ważne dla siebie i domu kwestie poruszali bez udziału dzieci. Mama wiedziała, że podróże ojca to część jego pracy. Musiał więc jeździć, ale napisanie po powrocie książki nie stanowiło jedynego powodu wypraw. On je lubił. Chciał tych podróży i ich potrzebował.

\section{A.S.: Czego nauczył Pana ojciec? Poza koszeniem trawy.}

M.S.: Tego akurat sam musiałem się nauczyć. On przekazał mi jednak podobnie praktyczne umiejętności: jazdy na nartach, chodzenia po górach, zachowania orientacji w lesie. Rozmów wychowawczych było mało. Prędzej mama była skłonna do ich przeprowadzania, zwłaszcza gdy coś mocno zawaliłem, co swego czasu często mi się zdarzało. Ojciec najwyżej wyrażał dezaprobatę i to wystarczało. Raz, gdy byłem dzieckiem, spuścił mi lanie, ale był przy tym tak nieszczęśliwy, że postanowiłem więcej nie stawiać go w takiej sytuacji. Decydującym instrumentem pedagogicznym był przykład życia obojga rodziców, nie gadanie.

9 J.J. Szczepański, Dziennik, t. 4, dz. cyt., s. 410-411. 
A.M.: Życie w cieniu wielkiego pisarza pomaga czy ogranicza?

M.S.: We wcześniejszej młodości nie wiem, czy zdawałem sobie sprawę, kim jest mój ojciec, a później nie czytałem jego książek. Przez wiele lat znałem tylko pierwsze rzeczy: Buty ${ }^{10}$, Polska jesienn ${ }^{11}$, Portki Odyssa ${ }^{12}$. Szanowałem twórczość ojca, ale mimo to sięgałem po książki innych autorów, bo wolałem inny język. Poza tym ojciec znaczył dla mnie wiele jako osoba, z którą obcowanie było ciekawe i przyjemne, a nie jako pisarz. Pisanie było jego praca, więc siłą rzeczy znajdowało się na drugim planie. Być może chodzi też o to, że musiałem wiele przeczytać i przetrawić, żeby docenić twórczość ojca. W efekcie poznałem ją jako dojrzały człowiek.

A.M.: Ojciec natomiast cenił Pana pisarstwo, między innymi uważał Girl guide ${ }^{13}$ za dowcipną, świetnie napisaną rzecz.

M.S.: Nie przesadzajmy, napisałem trzy książki, w tym jedną dla dzieci. I mam też takie, które napisałem i wyrzuciłem do kosza. Ojca cieszyły zresztą wszystkie nasze zabawy językowe - począwszy od „Byka Poetyckiego”, czyli gazetki przygotowywanej przez naszą trójkę w latach dorastania. A jeszcze był sekretarz rymowany - zabawa służąca pacyfikowaniu dzieci podczas słotnych dni w Kasince. Polegała na pisaniu wierszy do wcześniej przedstawionych rymów. Pamiętam, że ojciec ułożył do rymów: wywczas/ zdobywcza, nie w czasie/ nie da się, kandelabry/ makabry, następujący utwór: „Gdy się spostrzeżesz poniewczasie, że już dobiega końca wywczas,/ budzi się w tobie chuć zdobywcza, ale niestety już nie da się./ Wyjeżdżasz zatem gdzieś do Żywca, by szału zgasić kandelabry,/ podobny nędznej ludzkiej szmacie, co odwiedziła już połacie pałaców, nieba i makabry./ Ach, spocząć dajcie! Lecz nie dacie”.

\section{A.S.: Istniały na Helclów tematy zakazane?}

M.S.: Panowała powściągliwość, ale na zadane pytania odpowiadano rzeczowo. Inna sprawa, że rodzice byli dyskretni i nie poruszali każdej kwestii przy dzieciach. Kiedy podrośliśmy, zdarzały się różnice opinii między nami, ale z tego powodu nikt nie tracił prawa wyłuszczenia swoich racji. I nawet jeśli nie sposób było zawrzeć porozumienia, możliwe było sporządzenie protokołu rozbieżności.

Co równie ważne: rodzice stworzyli dom, w którym nie podnosiło się głosu. Nigdy. Nie było też tematów zamiatanych pod dywan. Gdy patrzę na to z pewnego oddalenia, uważam nasz małomieszczański dom za fenomen,

\footnotetext{
10 Tenże, Buty i inne opowiadania, wyd. 1, Kraków 1956.

11 Tenże, Polska jesień, wyd. 1, Kraków 1955.

12 Tenże, Portki Odyssa, wyd. 1, Warszawa 1954.

${ }_{13}$ M. Szczepański, Girl guide, wyd. 1, Chotomów 1992.
} 
bo rodzice pochodzili z dość konserwatywnych środowisk. Z dziadków poznałem jedynie mamę taty (jego ojciec, Aleksander Szczepański, oraz rodzice mamy - Stefania i Juliusz Wolscy - zmarli przed wojna), która wydawała mi się zawsze odrobinę skamieliną. Była poetką i tłumaczką z serbsko-chorwackiego, ale w obyciu raczej sztywna, poważna czy może smutna, bez poczucia humoru. Z dziadkiem poznała się w Rosji, gdzie jej rodzina żyła od dwóch pokoleń, przechowując dość archaiczny sposób myślenia i przeżywania, także prowadzenia domu. Ojciec opisuje zresztą koleje losu przodków w jednym z późniejszych opowiadań ${ }^{14}$.

Oddalenie od miejsc pochodzenia spowodowało, że rodzina babki przechowała wzorce życia od dawna nieistniejące w centralnej Polsce, także myślenia o patriotyzmie czy stosunku do religijności. Tymczasem mój ojciec, choć konspirował całą okupację i spędził pół roku w partyzantce AK-owskiej, daleki był od patriotycznych uniesień. Pozostał też dobrego gatunku agnostykiem, bo nie bał się konfrontacji ze stwierdzeniem: „nie wiem”. Myślę, że uczciwość ojca wzięła się z brutalnej weryfikacji materii życia, która zaszła podczas wojny. Ona zadziałała jak filtr, który oddzielił to, co ważne, od błahostek, prawdę od jej pozorów, kierując uwagę na to, co jest warte zabiegów. Równie formacyjny, choć w innym sensie, był dla mojego ojca wyjazd na stypendium do Harvardu w 1958 roku. A wcześniej podróże odbywane w dzieciństwie za sprawą ojca dyplomaty: Chicago, gdzie ukończył parę klas szkoły podstawowej, Zagrzeb, Bytom. Był przyzwyczajony do przemieszczania się, zmian punktów widzenia. Wojna, która wyzuła ojca, jego mamę i siostry z w miarę zamożnego, bezpiecznego życia i rzuciła do różnych przygodnych miejsc, które stawały się tymczasową przystanią, utwierdziła go w przekonaniu, że ludzie są różni i mają prawo tacy być. I należy czerpać z tego bogactwa.

A.S.: Religijność Pana ojca przypomina tę, o której pisał Zbigniew Herbert w wierszu Homilia: „bo dla księdza - proszę księdza - to jest wszystko takie proste/ Pan Bóg stworzył muchę żeby ptaszek miał co jeśćl Pan Bóg daje dzieci i na dzieci i na kościół”.

M.S.: Też tak to widzę. Dlatego byłem głęboko zdumiony, gdy przeczytałem w notatce z 15 lipca 1998 roku: „Matka, już umierająca, prosiła mnie, żebym codziennie się modlił. Obiecałem i robię to od tej pory, ale to jest gest, to nie jest prawdziwa modlitwa. Zawsze czuję przy tym fałsz, coś, czego nie umiem poprzeć prawdziwą wiarą. Jest w tym zasmucający posmak kłamstwa”"15. Jego mama, szalenie religijna osoba, zmarła w styczniu 1960 roku. Tato słowa dotrzymał, mimo że do Kościoła jako instytucji nigdy się nie przekonał. Raziły

${ }_{14}$ J.J. Szczepański, Rycerz Grzymata [w:] tegoż, Jeszcze nie wszystko, Kraków 1997.

15 Tenże, Dziennik, t. 6, dz. cyt., s. 764. Zob. też tenże, Dziennik, t. 2: 1957-1963, Kraków 2011, s. 339. 
go między innymi uproszczenia w opisie świata, hipokryzja, sprowadzenie wiary do wspólnej celebracji obrządków i uświęconego tradycją rytuału. Do tego w latach dziewięćdziesiątych dołożyło się upolitycznienie Kościoła w Polsce.

Ojciec był w moim przekonaniu osobą z bardzo silną potrzebą wiary, jednak pozbawiony „daru wiary”. Nie potrafił więc przebić się przez kościelną retorykę. A że był uczciwym facetem, uważał, że jeśli coś wybiera, to z akceptacją całego bogactwa inwentarza. Tyle że polski katolicyzm niósł ze sobą balast na tyle dla niego kłopotliwy, ile trudny do uniesienia.

A.M.: Dlaczego kontakt z takimi ludźmi, jak ksiądz Józef Tischner, Jerzy Turowicz czy kardynał Karol Wojtyła nie okazał się przekonujący?

M.S.: Dodałbym jeszcze ojca Karola Van Oosta - pierwszego przeora tynieckiego klasztoru po powrocie benedyktynów pod Kraków w 1939 roku - którego ojciec poznał dzięki mamie jeszcze w czasach ich narzeczeństwa ${ }^{16}$. To były światłe osoby, intelektualnie interesujące, ale nawet w kontaktach z nimi ojciec miał trudność przebicia się przez język. Jest o tym mowa w Dzienniku.

Domyślam się, że niereligijność taty była niełatwym doświadczeniem dla mamy, osoby głęboko wierzącej i praktykującej chrześcijaństwo w kontaktach z szeregiem ludzi przewijających się przez nasz dom. W tym zresztą rodzice byli podobni. Na pewno mama szanowała wybór ojca. Ten zresztą wykonywał czasami pewne gesty, na przykład uczestniczył w mszach przy okazji świąt czy w konkretnych intencjach. Od pierwszych chwil, kiedy zdecydowali się razem spędzić życie, mój ojciec zdawał sobie sprawę, że właśnie ze względu na głęboką duchowość przyszłej żony w sprawach wiary i religii nie może kluczyć. A uporząadkowanie tych kwestii jest miarą jego osobistej dojrzałości. Nie zakładał wniosków, do jakich dojdzie. Symboliczną konkluzją tych zmagań może być odpowiedź udzielona mamie po wyjściu z mszy wielkanocnej w 1984 roku, kiedy zapytała tatę, dlaczego nie robi znaku krzyża podczas błogosławieństwa: „Używanie znaków przynależących do wiary jest uzasadnione tylko prawdziwą wiarą," ${ }^{17}$. Przyznawał, że jej nie ma, bo wątpi w zmartwychwstanie Chrystusa, czyli w Jego boskość, a skoro tak, jak mógłby ją sobie nakazać? Myślę, że ojciec był wierny wątpliwościom do końca.

A.S.: Czym w tym kontekście były dla Jana Józefa filozofia i religia Wschodu?

M.S.: Fascynacją - taka odpowiedź wydaje mi się najbardziej adekwatna. Pojawiła się we wczesnej młodości i pozostał jej oddany. Bhagawadgitę, jedną ze świętych ksiąg hinduizmu, zabrał przecież na kampanię wrześniową, licząc, że

16 Zob. tenże, Dziennik, t. 1, dz. cyt., s. 145: „Człowiek bardzo mądry, doświadczony i europejski. Czułem się w jego obecności jak szczeniak i zachowywałem się okropnie”.

17 Tenże, Dziennik, t. 5: 1981-1989, Kraków 2017, s. 363. 
wojna będzie pozycyjna i znajdzie czas na lekturę ${ }^{18}$. Po 1945 roku skończył orientalistykę, choć wiedział już, że nie zwiąże przyszłości ze znajomością języka pali i sanskrytu. Zainteresowanie tą kulturą nie wpłynęło jednak na jego wybory religijne, bo ojciec ostrożnie podchodził do pomysłu czerpania z zasobów duchowych spoza swojej kultury, czyli judeochrześcijańskiej. Był do niej przywiązany, choć ciekaw innych tradycji. Chyba bliskie mu było zdanie, które moja żona, Maryna, usłyszała kiedyś od mistrza zen - Dae Soen Sa Nim Seung Sahna: „Nie szukaj obcej tradycji, masz własną. Tam jest wszystko”.

Pamiętam z Dziennika opis pejzażu oglądanego przez ojca podczas podróży przez jakieś okolice na Kielecczyźnie. Całkiem duży kawałek tekstu dotyczy świata, w którym właściwie nie ma nic ciekawego: pola, miedze, drzewa, mgły. Nie potrafiłem dociec, co było w tym dla niego ważne, bo zapewne było, skoro poświęcił temu tyle miejsca. Być może umiejętność dostrzegania rzeczy przez innych lekceważonych ukształtowała się w ojcu właśnie za sprawą filozofii Wschodu. A może to było po prostu jego dobre oko - to samo, które pozwalało mu poznać się na jakości obrazu, sprawnie odrzucając fałsz i udawanie.

A.M.: Jak funkcjonuje się $\mathrm{w}$ rodzinie $\mathrm{z}$ tak rozległymi tradycjami pisarskimi? By wymienić najważniejsze, poza Janem Józefem, nazwiska: Maryla Wolska (Pana prababcia), Beata Obertyńska (ciotka matki), Maria Kuncewiczowa (ciotka ojca), Maria Znatowicz-Szczepańska (Pana babcia), piszą obie Pana siostry (Anna Krasnowolska i Katarzyna Szczepańska-Kowalczuk) oraz siostrzeniec (Jan Krasnowolski).

M.S.: Ha, i co mam powiedzieć? Może tyle, że dla mnie to było środowisko naturalne - zawsze każdy coś pisał albo wymyślał, niekoniecznie od razu serio. Czasami były to żarty, ale właśnie takie nas bawiły. Jako dziecko myślałem zapewne, że tak jest w każdym domu.

Gwoli uzupełnienia tej wyliczanki muszę dodać, że moja żona jest współautorką wszystkich naszych scenariuszy i ma świetne ucho do dialogów. A mama, kiedy Kasia i ja byliśmy bardzo mali, prowadziła tak zwane dzienniki mowy, zapisując nasze słowa i wyrażenia na zlecenie prof. Stefana Szumana, psychologa i pedagoga. I jeśli o nic nie mam do rodziców pretensji, bo zawsze zachowywali się bardzo w porządku, tu zrobili mi krzywdę. Zdarza się bowiem wciąż, że panie psycholog, które znają tamte zapiski, spotykając mnie, zaczynają do mnie mówić tekstami z czasów, kiedy miałem pięć lat. I robią mi obciach przed jakąś publicznością...

${ }_{18}$ W siodle z Bhagawadgita. Rozmowa z Janem Józefem Szczepańskim, rozmawiali: D. Zańko, J. Gowin, Ł. Tischner, S. Wilkanowicz, „Znak” 2003, nr 4, s. 94-106. 
A.M.: Czy kiedykolwiek rozmawialiście, po co to pisanie?

M.S.: Nie przypominam sobie. Każdy ma jakieś sprawy do załatwienia z samym sobą, niektórzy mierzą się z nimi przez pisanie. U ojca do takich należały doświadczenia okupacyjne i wynikająca z nich trauma wojenna. Był świadkiem wydarzeń, które w ogóle nie powinny mieć miejsca, więc czuł przymus opowiedzenia o tym innym. Współczesnym i przyszłym pokoleniom. To była kwestia dania świadectwa, na przykład takim historiom, jak opowiedziana w noweli $B u t y^{19}$, czym rozpętał pierwszą po 1945 roku dyskusję o realiach walki partyzanckiej.

W Dzienniku notuje, że kiedy pisze, jest „mniej wydany na niepokój błahości istnienia”20, a pisanie to jedyna osiągalna przez niego forma zbawienia ${ }^{21}$. Przez całe życie zmagał się z pytaniem, które zadał mu kiedyś kilkuletni Misiak Kowalczuk, najmłodszy wnuk: „Po co są ludzie?”22. Ojciec pytał o to całe życie: jakie jest usprawiedliwienie naszego bycia w świecie? Czy można dociec sensu ludzkiej historii? Czego chce od nas Bóg? Nikt nam nie odpowie - sami musimy szukać. Ojciec robił to przez pisanie, które, jak wierzył, zaprowadzi go do czegoś prawdziwego. Albo istotnego.

\section{A.S.: Który z tekstów ojca jest Panu najbliższy?}

M.S.: Trzy czerwone róże i reszta świetnych opowiadań z tomu $R a f a^{23}$. Z przyjemnością przeczytałem też książki podróżnicze ojca ${ }^{24}$ - znajduję w tamtym opisie świata przenikliwe uwagi dotyczące nadchodzącego rozpadu jego ówczesnego kształtu. I zapowiedzi współczesnych nam problemów. W pewnym sensie Trzy czerwone róże to również obraz świata odchodzącego w niebyt, ale tam cenię precyzję opisu spraw pozornie nie do opisania. Trudnych emocjonalnie, niełatwych do uchwycenia. To rzecz ważna dla mnie także ze względu na sentyment do ciotki Zofii Kernowej (matki Anny Turowiczowej), która okazała wiele serca i nieocenionego wsparcia rodzicom mojej mamy. I choć bywała zupełnie nieznośna w bezpośrednim obcowaniu, bardzo ją kochałem.

A.M.: Powiedział Pan, że ojciec przestał pisać Dziennik, kiedy choroba uniemożliwiła mu pisanie. Widać w tym zamiar towarzyszenia światu pisaniem do końca, niemal do ustania możliwości komunikowania się.

19 J.J. Szczepański, Buty, „Tygodnik Powszechny” 1947, nr 6, s. 8-9.

20 Tenże, Dziennik, t. 4, dz. cyt., s. 72.

${ }^{21}$ Tamże, s. 605.

22 J.J. Szczepański, Dziennik, t. 6, dz. cyt., s. 397.

${ }^{23}$ Tenże, Rafa, wyd. 1, Warszawa 1974.

${ }^{24}$ Tenże, Zatoka Biatych Niedżwiedzi, wyd. 1, Kraków 1960; tenże, Do raju i z powrotem, wyd. 1, Warszawa 1964; tenże, Czarne i biate, wyd. 1, Kraków 1965; tenże, Świat wielu czasów, wyd. 1, Kraków 1969; tenże, Koniec westernu, Warszawa 1971. 
M.S.: Pamiętam, że kiedy parę miesięcy po tej decyzji ojciec się rozchorował i leżał w szpitalu pogrążony w śpiączce, czytałem mu podczas odwiedzin różne teksty, także listy do niego przychodzące. „Pamiętasz list Władysława Bartoszewskiego?” - zapytałem ojca, gdy szczęśliwe wrócił do domu. Profesor opisywał między innymi niedawne spotkanie z Janem Nowakiem-Jeziorańskim, podczas którego dawny kurier okropnie go za coś ochrzanił, wymyślając mu od smarkaczy. Tato zapewnił, że nic nie pamięta. I tak rozmawiamy, aż nagle mówi: „ale Nowak-Jeziorański to już naprawdę przesadził, tak objeżdżając Bartoszewskiego"... Wiemy o sobie naprawę niewiele.

Kraków, 24 października 2019 roku 